\title{
In vitro effect of intracanal medicaments on strict anaerobes by means of the broth dilution method
}

\section{Efeito in vitro de medicações intracanal sobre anaeróbios estritos pelo método de diluição em caldo}

\author{
Odila Pereira da Silva ROSA* \\ Sérgio Aparecido TORRES** \\ Claudio Maniglia FERREIRA*** \\ Flaviana Bombarda de Andrade FERREIRA***
}

\begin{abstract}
ROSA, O. P. da S.; TORRES, S. A.; FERREIRA, C. M.; FERREIRA, F. B. de A. In vitro effect of intracanal medicaments on strict anaerobes by means of the broth dilution method. Pesqui Odontol Bras, v. 16, n. 1, p. 31-36, jan./mar. 2002 .
\end{abstract}

\begin{abstract}
The determination of bacterial susceptibility to intracanal medicaments is a necessity. Nevertheless, few studies utilize the proper methodology to carry out that evaluation with anaerobes. In this study, the steps of a broth dilution method, carried out in microplates (microdilution) and tubes (macrodilution), to test the effect of traditional intracanal medicaments on anaerobic bacteria are described. The results are presented as values of minimal inhibitory and bactericidal concentrations (MIC and MBC). Standardized inocula of the anaerobic bacteria Prevotella nigrescens (ATCC 33563), Fusobacterium nucleatum (ATCC 25586) and Clostridium perfringens (ATCC 13124), in reinforced Clostridium medium (RCM) and supplemented Brucella broth, were submitted to different concentrations of calcium hydroxide, chlorhexidine digluconate, camphorated paramonochlorophenol and formocresol solutions. The drugs were diluted in the same culture broths, in microplates and tubes, and were then incubated in anaerobiosis jars at $37^{\circ} \mathrm{C}$ for 48 or 96 hours. The determination of MICs was carried out through visual and spectrophotometric readings, and the determination of MBCs, through the plating of aliquots on RCM-blood agar. For that kind of study, the macromethod with spectrophotometric reading should be the natural choice. MICs and MBCs obtained with the macromethod were compatible with the known clinical performance of the studied medications, and the values varied according to the bacteria and culture media employed. RCM was the most effective medium and C. perfringens, the most resistant microorganism.
\end{abstract}

UNITERMS: Root canal therapy; Root canal irrigants; Microbiology; Bacteria, anaerobic.

\section{INTRODUCTION}

Irrigation and mechanical cleaning of the root canal are of the utmost importance in reducing the amount of bacteria during the endodontic treatment. However, without the utilization of intracanal medication, half of the endodontically treated root canals would still present with bacteria in the second session ${ }^{2}$. Intracanal dressing, thus, helps eliminating bacteria that are not affected by the chemical-mechanical preparation and prevents, or at least delays, the reinfection of canals between sessions ${ }^{17}$. Therefore, any medication chosen for intracanal application must be evaluated as to its antimicrobial activity by means of in vitro susceptibility tests. Usually, the evaluation is carried out on facultative and aerobic bacteria, and the agar diffusion technique is employed. However, the infection of root canals is polybacterial, with the prevalence of anaerobic bacteria ${ }^{20}$, whose susceptibility is ideally determined by means of dilution tests in agar or broth ${ }^{7}$.

In the endodontic literature, evaluations of the susceptibility of anaerobes to antimicrobial agents are relatively scarce; besides, studies carried out with dilution quantitative techniques practically do not exist. Hence, the aim of this study was to standardize a broth dilution test, utilizing traditional intracanal medicaments and reference anaerobic strains, in order to guarantee the reproducibility of the results and correlate the in vitro

\footnotetext{
*Associate Professor; **PhD, Professor, Department of Biological Sciences; ***Graduate Students (Master of Science), Endodontics - Bauru Dental School, University of São Paulo.
} 
ROSA, O. P. da S.; TORRES, S. A.; FERREIRA, C. M.; FERREIRA, F. B. de A. In vitro effect of intracanal medicaments on strict anaerobes by means of the broth dilution method. Pesqui Odontol Bras, v. 16, n. 1, p. 31-36, jan./mar. 2002.

results with the clinical performance of these substances.

\section{MATERIAL AND METHODS Microorganisms and drugs}

Reference strains of Prevotella nigrescens (ATCC 33563) and Fusobacterium nucleatum (ATCC 25586), representative of the most frequently isolated anaerobes in endodontic infections, as well as of Clostridium perfringens (ATCC 13124), commonly employed in tests with antibiotics, were utilized. Bacteria were maintained at $-20^{\circ} \mathrm{C}$ in cryotubes containing skim milk $(0.5 \mathrm{ml}$ of active growth added to $0.5 \mathrm{ml}$ of a sterile $20 \%$ solution of powdered skim milk). Solutions of $10 \%$ calcium hydroxide (Biodinâmica, Brazil); $\%$ chlorhexidine digluconate (FGM, Brazil); 35\% camphorated paramonochlorophenol (PMCC) (Inodon, Brazil) and Formocresol (Probem, Brazil) were evaluated.

\section{Microdilution test ${ }^{21}$}

In order to select the dilutions that would be utilized in the broth macrodilution test, microdilution tests were carried out in microplates. Initially, two screw-capped tubes, measuring $16 \times 160 \mathrm{~mm}$ and containing $10 \mathrm{ml}$ of the reinforced clostridial medium (RCM, Oxoid, USA) or Brucella broth (Difco, USA) supplemented with $5 \mu \mathrm{g} / \mathrm{ml}$ of hemin (Sigma, USA) and $10 \mu \mathrm{g} / \mathrm{ml}$ of vitamin $\mathrm{K}_{1}$ (Merck, Germany) were inoculated with $0.1 \mathrm{ml}$ of the skim milk stock and incubated in anaerobiosis (jar and envelopes Gaspak-BBL, USA), at $37^{\circ} \mathrm{C}$, for 24 hours. As soon as growth was observed, two additional subcultures were made, in the same way, with incubation in anaerobiosis at $37^{\circ} \mathrm{C}$, for 24 hours, in order to obtain bacteria in an exponential phase of growth. After the last incubation, the turbidity of the tubes was read in an Ultrospec 1000 spectrophotometer (Pharmacia, USA), at $540 \mathrm{~nm}^{19}$. Having the $0.5 \mathrm{McF}$ arland standard as a reference, the dilution of the cultures in RCM and Brucella broths was carried out up to the concentration of $5 \times 10^{5}$ colony forming units $/ \mathrm{ml}(\mathrm{CFU} / \mathrm{ml})^{23}$. This standardized inoculum was always used within 30 minutes after the adjustment ${ }^{25}$.

The microdilution test was carried out in a sterile flat-bottomed microplate, with 96 wells (Corning, USA). Initially, each well received $100 \mu 1$ of $\mathrm{RCM}$ or supplemented Brucella broth. Next, $100 \mu 1$ of the drug were added to the first well, and serial two-fold dilutions were made. Then, each well re- ceived $100 \mu \mathrm{l}$ of the standardized inoculum. The tests were carried out in duplicate. Six controls were utilized for all tests. Incubation with PMCC and formocresol was carried out separately, due to the activity of the vapors of those medicaments. Microplates were incubated in anaerobiosis, at $37^{\circ} \mathrm{C}$ for 48 hours.

In the face of the impossibility of visual reading of growth in the wells, and considering the impossibility of determining values of minimal inhibitory concentration (MIC), the determination of minimal bactericidal concentration (MBC) was carried out $^{13}$. For that, $25 \mu 1$ from each well were dispensed on Petri plates containing RCM agar with 5\% sheep blood (RCM-blood), each plate holding 25 drops. These plates were incubated in anaerobiosis, at $37^{\circ} \mathrm{C}$ for 48 hours.

\section{Macrodilution test ${ }^{21}$}

The sequence was the same previously described, but it was carried out in tubes measuring $13 \times 100 \mathrm{~mm}$ with screw caps, which initially received $2.5 \mathrm{ml}$ of RCM or supplemented Brucella broth. After obtaining the desired concentrations of the medicaments, according to serial two-fold dilutions, all tubes received $2.5 \mathrm{ml}$ of the standardized inoculum. Positive and negative controls were included. Before and after incubation at $37^{\circ} \mathrm{C}$ in anaerobiosis, for 48 hours for RCM broth and for 96 hours for Brucella broth, the reading of the optical density (OD) of all tubes was carried out in the spectrophotometer and, whenever possible, also by means of visual reading. Once MIC had been established, MBC was determined by means of spreading, with a Drigalsky loop, $25 \mu 1$ of the material from each tube without growth on Petri plates measuring $52 \times 12 \mathrm{~mm}$, which contained $5 \mathrm{ml}$ of RCM-blood agar. The samples were incubated in anaerobiosis, at $37^{\circ} \mathrm{C}$ for 48 hours.

\section{RESULTS}

The values of MBC obtained with the microdilution tests are shown in Tables 1 and 2, for RCM and Brucella broth, respectively. MICs and MBCs obtained through the macrodilution test in RCM broth are described in Table 3, and those obtained in Brucella broth, in Table 4.

\section{DISCUSSION}

The method recommended by the National Committee for Clinical Laboratory Standards (NCCLS, USA) to test the susceptibility of anaero- 
ROSA, O. P. da S.; TORRES, S. A.; FERREIRA, C. M.; FERREIRA, F. B. de A. In vitro effect of intracanal medicaments on strict anaerobes by means of the broth dilution method. Pesqui Odontol Bras, v. 16, n. 1, p. 31-36, jan./mar. 2002.

bes is the agar dilution method, with the alternative of macrodilution test in broth when there are few isolated bacteria and agents to be tested ${ }^{7}$. The agar diffusion method is counterindicated ${ }^{8}$. Since both methods are expensive and very time-consuming, the microdilution test has been developed.

With antibiotics, the results obtained by means of this method are pretty similar to those obtained with the agar dilution method ${ }^{12}$. In general, the utilized dilution is smaller than that employed in macrodilution in broth $^{3}$, which makes the reading easier, since the transparency of drugs does not complicate the naked-eye visualization of the changes that take place in the wells. However, the solutions utilized in this study significantly change the employed media, which makes impossible to visually determine MICs. For that reason, MBCs were determined (Tables 1 and 2), even though mi-

TABLE 1 - Minimal bactericidal concentrations $(\mu \mathrm{g} / \mathrm{ml})$ of substances employed against anaerobic bacteria - microdilution test in RCM broth.

\begin{tabular}{c|c|l|l|c}
\hline \hline Bacteria & $\mathrm{Ca}(\mathrm{OH})_{2}$ & $\begin{array}{l}\text { Chlorhe- } \\
\text { xidine }\end{array}$ & PMCC* & Formocresol \\
\hline F. nucleatum & $1,562.50$ & 0.30 & 0.0025 & 92.75 \\
\hline P. nigrescens & $3,125.00$ & 0.0044 & 0.33 & 740.00 \\
\hline C. perfringens & $>50,000$ & 156.25 & 340.00 & 92.75 \\
\hline \hline
\end{tabular}

* $35 \%$ camphorated paramonochlorophenol. crodilution is not adequate for that procedure since with the small amount of inoculum utilized there is the risk of not detecting the elimination of $99.9 \%$ of the viable $\mathrm{CFU}$ in the broth $(\mathrm{MBC})^{4,13}$.

The discrepancy between MBCs obtained through the micromethod and by means of the macromethod (Tables 1 to 4 ) - the values obtained with the micromethod were much lower or higher than those obtained through the macromethod confirms that the first method is inadequate to this determination. Nevertheless, this fact does not restrain the future utilization of the micromethod to determine the MIC of medications utilized in endodontics, with readings of growth carried out with the photometer employed in the technique of enzyme immunoassay (ELISA). SHAPIRO et al. ${ }^{14}$ (1994), who utilized the microdilution test for thymol, did not observe any difference between the

TABLE 2 - Minimal bactericidal concentrations $(\mu \mathrm{g} / \mathrm{ml})$ of substances employed against anaerobic bacteria - microdilution test in Brucella broth.

\begin{tabular}{c|c|c|c|c}
\hline \hline Bacteria & $\mathrm{Ca}(\mathrm{OH})_{2}$ & $\begin{array}{c}\text { Chlorhe- } \\
\text { xidine }\end{array}$ & $\mathrm{PMCC}^{*}$ & Formocresol \\
\hline F. nucleatum & $6,250.00$ & 0.00014 & 10.62 & 185.00 \\
\hline P. nigrescens & $3,125.00$ & 0.00050 & 0.33 & 0.36 \\
\hline C. perfringens & $>50,000$ & 39.06 & 170.00 & 742.00 \\
\hline \hline
\end{tabular}

*35\% camphorated paramonochlorophenol.

TABLE 3 - Minimal inhibitory (MIC) and bactericidal concentrations (MBC) $(\mu \mathrm{g} / \mathrm{ml})$ of substances employed against anaerobic bacteria - macrodilution test in RCM broth.

\begin{tabular}{c|c|c|c|c|c|c|c|c}
\hline \hline \multirow{2}{*}{ Bacteria } & \multicolumn{2}{|c|}{$\mathrm{Ca}(\mathrm{OH})_{2}$} & \multicolumn{2}{c|}{ Chlorhexidine } & \multicolumn{2}{c|}{ PMCC* } & \multicolumn{2}{c}{ Formocresol } \\
\cline { 2 - 9 } & MIC & MBC & MIC & MBC & MIC & MBC & MIC & MBC \\
\hline F. nucleatum & 781.25 & $1,562.50$ & 0.30 & 1.22 & 340.00 & 680.00 & 371.00 & $1,480.00$ \\
\hline P. nigrescens & 781.25 & $1,562.50$ & 0.30 & 1.22 & 85.00 & 340.00 & 742.00 & $1,480.00$ \\
\hline C. perfringens & $6,250.00$ & $6,250.00$ & 2.44 & 2.44 & 680.00 & 680.00 & 742.00 & $1,480.00$ \\
\hline \hline
\end{tabular}

* $35 \%$ camphorated paramonochlorophenol.

TABLE 4 - Minimal inhibitory (MIC) and bactericidal concentrations (MBC) ( $\mu \mathrm{g} / \mathrm{ml})$ of substances employed against anaerobic bacteria - macrodilution test in Brucella broth.

\begin{tabular}{c|c|c|c|c|c|c|c|r}
\hline \hline \multirow{2}{*}{ Bacteria } & \multicolumn{2}{|c|}{$\mathrm{Ca}(\mathrm{OH})_{2}$} & \multicolumn{2}{c|}{ Chlorhexidine } & \multicolumn{2}{c|}{ PMCC* } & \multicolumn{2}{c}{ Formocresol } \\
\cline { 2 - 9 } & MIC & MBC & MIC & MBC & MIC & MBC & MIC & MBC \\
\hline F. nucleatum & 781.25 & 781.25 & 0.15 & 0.15 & 340.00 & 340.00 & 371.00 & 742.00 \\
\hline P. nigrescens & 781.25 & 781.25 & 0.15 & 0.15 & 85.00 & 170.00 & 742.00 & $1,480.00$ \\
\hline C. perfringens & $1,562.50$ & $1,562.50$ & 2.44 & 2.44 & 680.00 & 680.00 & 742.00 & 742.00 \\
\hline \hline
\end{tabular}

* $35 \%$ camphorated paramonochlorophenol. 
ROSA, O. P. da S.; TORRES, S. A.; FERREIRA, C. M.; FERREIRA, F. B. de A. In vitro effect of intracanal medicaments on strict anaerobes by means of the broth dilution method. Pesqui Odontol Bras, v. 16, n. 1, p. 31-36, jan./mar. 2002.

MICs obtain by means of the micro and macromethods for the anaerobic bacterium Porphyromonas gingivalis.

The results displayed in Tables 3 and 4 indicate chlorhexidine as the drug that was efficient in the lowest concentrations, followed by PMCC, formocresol and calcium hydroxide, for all bacteria, which confirms that the first drug shows good results in eliminating anaerobes ${ }^{9,11,24,26}$.

Despite the need for higher concentrations of calcium hydroxide for the obtainment of an antimicrobial effect, the results do contest the absence or low intensity of the activity of that drug, which has been shown by means of different in vitro $\operatorname{methods}^{1,15}$. However, the present results are in agreement with those reported by SUZUKI et al. ${ }^{22}$ (1999), who found MICs ranging from 1,560 to $25,000 \mu \mathrm{g} / \mathrm{ml}$, for twelve distinct anaerobes, demonstrating that the minimal inhibitory concentrations depend on the studied bacterium.

The good performance of PMCC against anaerobic bacteria, which has been previously observed by other authors, was confirmed ${ }^{5,16}$. The liquid form, which presents a higher antimicrobial effect than the clinically utilized vapor form ${ }^{6}$, was employed. Therefore, the minimal bactericidal and inhibitory concentrations of the vapor form must be higher than the those presented here. According to SPANGBERG $^{18}$ (1994), when utilizing the vapor form, the concentration of the medicament should be 100 to 1,000 times higher than that employed when utilizing the liquid form.

OHARA et al. ${ }^{11}$ (1993) tested the in vitro effect of vapors of volatile drugs and found out that formocresol was more efficient than PMCC. In their study, except for P. nigrescens, MICs for PMCC and formocresol were similar; MBCs were similar or lower (with the variation of one dilution) for PMCC, depending on the utilized medium.

Comparisons between the three most commonly utilized substances can be found in the literature, with divergences as to the antimicrobial activity against species of anaerobic bacteria, mainly due to differences in the employed methodologies and in the interpretation of data. Nevertheless, in a clinical evaluation, BARBOSA et al. ${ }^{1}$ (1997) did not observe any significant difference between the percentages of cases rendered negative for bacteria after receiving intracanal dressings of $\mathrm{PMCC}$, calcium hydroxide and chlorhexidine $169 \%, 73 \%$ and $78 \%$, respectively). This fact is especially important because it refers the clinician to other criteria, besides antibacterial efficacy, for choosing an intracanal agent, such as toxicity, inflammatory potential, diffusibility, ability to neutralize endotoxins and stimulate tissual repair in the periapical area.

It is worth to mention that the bacterium Clostridium perfringens, which is not a member of the oral cavity normal flora and is commonly used as a test control, was the microorganism with the most resistant profile to all drugs.

In relation to the utilized culture media, employing a standardized inoculum, the growth of the positive control (without any drug) of all bacteria in supplemented Brucella broth after incubation for 96 hours (OD between 1,000 and 1,400) was smaller than that observed in RCM broth after 48 hours (OD $\geq 2,000)$. RCM broth always presented the best performance, which was also verified in the activation of strains. Yet, the averages of MICs and MBCs were not expressively different for the three species of bacteria, in both media, with final values quite similar or showing differences of one or two lower dilutions in Brucella broth. In the future, other broths should be tested.

It is known that pre-reduced anaerobically sterilized media (PRAS) allow for a better growth of anaerobes, but its preparation is impossible in most clinical laboratories ${ }^{10}$. That justifies the attempt to establish a practicable technique for average laboratories that have anaerobiosis jars, which allows for the preparation of the rich media one day before the experiment. The methodology has shown a good performance with the tested microorganisms. It may present problems when employed with more fastidious microorganisms, for which more intensive subcultures do not afford the growth proper to constitute the inoculum for susceptibility tests - that growth must preferably occur within 18 to 24 hours $^{19}$.

In vitro studies, such as the present research, are carried out with isolated bacteria while endodontic infections are usually mixed - with complex microbial interactions and an average concentration of viable bacteria of $10^{7.7} \mathrm{CFU} / \mathrm{g}$ of sample ${ }^{27}-$, which may interfere with the action of different medicaments. In spite of that, the importance of presenting quantitative data $(\mu \mathrm{g} / \mathrm{ml})$ on the antimicrobial effect of drugs must be pointed out, since those studies are based on standardized methodologies that can be reproduced by microbiology laboratories that do not have the same resources as great research centers. 
ROSA, O. P. da S.; TORRES, S. A.; FERREIRA, C. M.; FERREIRA, F. B. de A. In vitro effect of intracanal medicaments on strict anaerobes by means of the broth dilution method. Pesqui Odontol Bras, v. 16, n. 1, p. 31-36, jan./mar. 2002.

\section{CONCLUSIONS}

Spectrophotometric reading renders good reliability to the interpretation of MIC. MICs and MBCs obtained by means of the macrodilution method are consistent with the clinical performance of the employed medicaments and confirm the indication of the macromethod for in vitro studies with small number of anaerobes. RCM was revealed as the best option for future studies because it enables bacterial growth in less time.

\section{ACKNOWLEDGMENT}

To The State of São Paulo Research Foundation, for the financial support (process number 98/04449-0).

ROSA, O. P. da S.; TORRES, S. A.; FERREIRA, C. M.; FERREIRA, F. B. de A. Efeito in vitro de medicações intracanal sobre anaeróbios estritos pelo método de diluição em caldo. Pesqui Odontol Bras, v. 16, n. 1, p. 31-36, jan./mar. 2002 .

A determinação da suscetibilidade bacteriana aos medicamentos intracanal é uma necessidade, mas são poucos os estudos que utilizam metodologia própria para anaeróbios estritos nessa avaliação. Neste estudo, são descritos os passos de um método de diluição em caldo, feito em microplacas (microdiluição) e em tubo (macrodiluição), para testar a ação de medicamentos intracanal tradicionais sobre bactérias anaeróbias estritas, com apresentação dos resultados em Concentrações Inibitória e Bactericida Mínimas (CIM e CBM). Inóculos padronizados dos anaeróbios Prevotella nigrescens (ATCC 33563), Fusobacterium nucleatum (ATCC 25586) e Clostridium perfringens (ATCC 13124), em caldo Reinforced Clostridium Medium (RCM) e caldo Brucella suplementado, foram submetidos a diferentes concentrações de soluções de hidróxido de cálcio, digluconato de clorexidina, paramonoclorofenol canforado e formocresol, diluídas nos mesmos caldos de cultura, em microplacas e tubos, e depois incubados em jarras de anaerobiose a $37^{\circ} \mathrm{C}$ por $48 \mathrm{~h}$ ou 96 h. A determinação das CIMs foi feita através de leituras visual e em espectrofotômetro, e das CBMs, pela semeadura de alíquotas em ágar RCM-sangue. Para esse tipo de estudo, o macrométodo com leitura em espectrofotômetro deve ser a escolha natural. As CIMs e CBMs do macrométodo foram compativeis com seu conhecido desempenho clínico, variando com as bactérias e meios de cultura empregados. O caldo RCM foi o mais efetivo e o C. perfringens, o microrganismo mais resistente.

UNITERMOS: Tratamento do canal radicular; Irrigantes do canal radicular; Microbiologia; Bactérias anaeróbias.

\section{BIBLIOGRAPHIC REFERENCES}

1. BARBOSA, C. A. M.; GONÇALVES, R. B.; SIQUEIRA Jr., J. F. et al. Evaluation of the antibacterial activities of calcium hydroxide, chlorhexidine and camphorated paramonochlorophenol as intracanal medicaments. A clinical and laboratorial study. J Endod, v. 23, n. 5, p. 297-300, May 1997.

2. BYSTRÖM, A.; CLAESSON, R.; SUNDQVIST, G. The antibacterial effects of camphorated paramonochlorophenol, camphorated phenol and calcium hydroxide in the treatment of infected root canals. Endod Dent Traumatol, v. 1, n. 5, p. 170-175, Oct. 1985.

3. CITRON, D. Susceptibility testing of anaerobes. Anaerobe workshop. IADR Meeting, Nice, France, 1998.

4. FINEGOLD, S. M.; BARON, E. J. Métodos para evaluar la efectividad antimicrobiana. In:_ Diagnóstico microbiológico. 7. ed. Buenos Aires : Panamericana, 1989. Cap. 13. p. 190-210.

5. GEORGOPOULOU, M.; KONTAKIOTIS, E.; NAKOU, M. In vitro evaluation of the effectiveness of calcium hydroxide and paramonochlorophenol on anaerobic bacteria from the root canal. Endod Dent Traumatol, v. 9, n. 6, p. 249-53, Dec. 1993.

6. HAAPASALO, M.; ORSTAVIK, D. In vitro infection and disinfection of dentinal tubules. J Dent Res, v. 66, n. 8, p. 1375-1379, Aug. 1987.

7. HINDLER, J. A.; HOWARD, B. J.; KEISER, J. F. Antimicro- bial agents and antimicrobial susceptibility testing. Chap. 9. In: HOWARD, B. J. et al. (ed.) Clinical and pathogenic microbiology. 2. ed. St. Louis : Mosby, 1994. p. 163.

8. KONEMAN, E. W.; ALLEN, S. D.; JANDA, W. M. et al. The anaerobic bacteria. In: Color atlas and textbook of diagnostic microbiology. 5. ed. Philadelphia : Lippincott, 1997. Cap. 14, p. 709-784.

9. LEONARDO, M.; TANOMARU FILHO, M.; SILVA, L. A. B. et al. In vivo antimicrobial activity of $2 \%$ chlorhexidine used as a root canal irrigating solution. J Endod, v. 25, n. 3, p. 167-171, Mar. 1999.

10. MANGELS, J. I.; DOUGLAS, B. P. Comparison of four commercial Brucella agar for growth of anaerobic organisms. J Clin Microbiol, v. 27, n. 10, p. 2268-2271, Oct. 1989.

11. OHARA, P.; TORABINEJAD, M.; KETTERING, J. D. Antibacterial effects of various endodontic medicaments on selected anaerobic bacteria. J Endod, v. 19, n. 10, p. 498-500, Oct. 1993

12. ROSENBLATT, J. E.; MURRAY, P. R.; SONNENWIRTH, A. C. et al. Comparison of anaerobic susceptibility results obtained by different methods. Antimicrob Agents Chemother, v. 15, n. 3, p. 351-355, Mar. 1979.

13. SCHOENKNECHT, F. D.; SABATH, L. D.; THORNSBERRY, C. Pruebas especiales de susceptibilidad. In: LENETTE, E. H. et al. Manual de microbiologia clínica. 4. ed. 
ROSA, O. P. da S.; TORRES, S. A.; FERREIRA, C. M.; FERREIRA, F. B. de A. In vitro effect of intracanal medicaments on strict anaerobes by means of the broth dilution method. Pesqui Odontol Bras, v. 16, n. 1, p. 31-36, jan./mar. 2002.

Buenos Aires : Panamericana, 1987. Cap. 103, p. $1225-1228$.

14. SHAPIRO, S.; MEIER, A.; GUGGENHEIM, B. The antimicrobial activity of essential oils and essential oil components towards oral bacteria. Oral Microbiol Immunol, v. 9, n. 4, p. 202-208, Aug. 1994.

15. SIQUEIRA Jr., J. F.; UZEDA, M. Disinfection by calcium hydroxide pastes of dentinal tubules infected with two obligate and one facultative anaerobic bacteria. $\mathbf{J}$ Endod, v. 22, n. 12, p. 674-676, Dec. 1996.

16. SIQUEIRA Jr., J. F.; LOPES, H. P.; UZEDA, M. Atividade antibacteriana de medicamentos endodônticos sobre bactérias anaeróbias estritas. Rev Assoc Paul Cir Dent, v. 50, n. 4, p. 326-331, jul./ago. 1996.

17. SIQUEIRA Jr., J. F.; LUQUETTE, L. B.; WERNECK, H. F. et al. Effectiveness of formocresol and calcium hydroxide camphorated paramonochlorophenol paste in preventing entire root canal recontamination by bacteria from saliva. An in vitro study. Braz Endod J, v. 2, n. 2, p. 23-25, 1997.

18. SPANGBERG, L. S. W. Intracanal medication. In: INGLE, J. I.; BAKLAND, E. K. (eds.). Endodontics. 4. ed. Baltimore : Williams \& Wilkins, 1994. p. 636.

19. STALONS, D. R.; THORNSBERRY, C.; DOWEL Jr., V. R. Effect of culture medium and carbon dioxide concentration on growth of anaerobic bacteria commonly encountered in clinical specimens. App1 Microbiol, v. 27, n. 6, p. 1098-1104, June 1974.
20. SUNDQVIST, G. Ecology of root canal flora. J Endod, v. 18, n. 9, p. 427-430, Sept. 1992.

21. SUTTER, V. L.; CITRON, D. M.; EDELSTEIN, M. A. C. et al. Wadsworth anaerobic bacteriology manual. 4. ed. Belmont : Star, 1985. p. 79-89.

22. SUZUKI, K.; HIGUCHI, N.; HORIBA, N. et al. Antimicrobial effect of calcium hydroxide on bacteria isolated from infected root canals. Dent Japan, v. 35, p. 43-47, Mar. 1999.

23. SWENSON, J. M.; THORNSBERRY, C. Preparing inoculum for susceptibility testing of anaerobes. J Clin Microbiol, v. 19, n. 3, p. 321-325, Mar. 1984.

24. VAHDATY, A.; FORD, T. R. P.; WILSON, R. F. Efficacy of chlorexidine in disinfecting dentinal tubules in vitro. Endod Dent Traumatol, v. 9, n. 6, p. 243-248, Dec. 1993.

25. WASHINGTON II, J. A. Pruebas de susceptibilidad: dilución en agar. In: LENETTE, E. H. et al. Manual de microbiologia clínica. 4. ed. Buenos Aires : Panamericana, 1987. Cap. 100, p. 1200-1205.

26. WHITE, R. R.; HAYS, G. L.; JANER, L. R. Residual antimicrobial activity after canal irrigation with chlorexidine. $\mathbf{J}$ Endod, v. 23, n. 4, p. 229-231, Apr. 1997.

27. ZAVISTOSKY, J.; DZINK, J.; ONDERDONK, A. et al. Quantitative bacteriology of endodontic infections. Oral Surg, v. 49, n. 2, p. 171-174, Feb. 1980. 